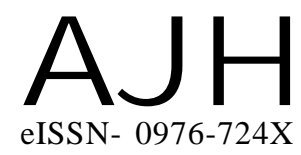

Received : 18.10 .2015

Revised : 01.05.2016

Accepted : 10.05.2016
Author for Correspondence :

\section{G.R. KISHORE}

Department of Horticulture, C.C.R

(P.G.) College, MUZAFFARNAGAR

(U.P.) INDIA

Email : drgrkishore@gmail.com
THEASIAN JOURNALOF HORTICULTURE

Volume 11 | Issue 1 | June, 2016 | 159-162

Visit us -www.researchjournal.co.in

RESEARCH PAPER

DOI : 10.15740/HAS/TAJH/11.1/159-162

\title{
Effect of different levels of nitrogen, phosphorus and potassium on floral characters of African Marigold (Targetes erecta L.) cv. PUSA NARANGI GAINDA
}

\section{G.R. KISHORE}

ABSTRACT : A field experiment was conducted on African marigold with different levels of fertilizer doses i.e. $0 \mathrm{~g}, 11 \mathrm{~g}$ and $22 \mathrm{~g}$ of $\mathrm{N}_{2}, 0 \mathrm{~g}, 10 \mathrm{~g}$ and $20 \mathrm{~g}$ of $\mathrm{P}_{2} \mathrm{O}_{5}$ and $0 \mathrm{~g}, 4 \mathrm{~g}$ and $8 \mathrm{~g}$ of $\mathrm{K}_{2} \mathrm{O} /$ $\mathrm{m}^{2}$ at the field of Department of Horticulture, C.C.R. (P.G.) College, Muzaffarnagar (U.P.) during the winter season 2008-2009. Most of the flowering characters were found increased at higher level of N, P and K. By observing the data it can be suggested that $150 \mathrm{~kg} / \mathrm{ha} \mathrm{N}, 100 \mathrm{~kg} / \mathrm{ha} \mathrm{P}_{2} \mathrm{O}_{5}$ and $30 \mathrm{~kg} / \mathrm{ha} \mathrm{K}_{2} \mathrm{O}$ were found suitable dose for the commercial cultivation of African marigold in western plain zone of U.P.

KEY WORDS : African marigold, Nitrogen, Phosphorus, Potassium

HOW TO CITE THIS ARTICLE : Kishore, G.R. (2016). Effect of different levels of nitrogen, phosphorus and potassium on floral characters of African Marigold (Targetes erecta L.) cv. PUSA NARANGI GAINDA. Asian J. Hort., 11(1) : 159-162, DOI : 10.15740/HAS/TAJH/11.1/159-162. 